\title{
НАРОДНОЕ ПРОСВЕЩЕНИЕ КАК ФОРМА КУЛЬТУРНО-ПРОСВЕТИТЕЛЬСКОЙ ДЕЯТЕЛЬНОСТИ В ОРЛОВСКОЙ ГУБЕРНИИ КОНЦА ХІХ - НАЧАЛА ХХ ВЕКОВ
}

\section{NATIONAL ENLIGHTENMENT AS A FORM OF CULTURAL AND EDUCATIONAL ACTIVITY IN THE OREL PROVINCE OF THE LATE XIX - EARLY XX CENTURIES \\ E. Sleptsova}

Summary: In this article, the author examines in detail one of the forms of cultural and educational activities in the life of society - public education, which played a significant role in improving literacy, expanding horizons, moral education of the provincial population of the province.

Keywords: enlightenment, culture, intelligentsia, people's libraries, public reading committees, literacy, leisure.

\author{
Слепцова Елена Перфильевна \\ к.и.н., дочент, ФГБОУ ВО «БрянскИй ГАУ» \\ elenaslep125@mail.ru
}

Аннотация: В данной статье автор подробно рассматривает одну из форм культурно-просветительной деятельности в жизни общества - народное просвещение, которое сыграло значительную роль в повышении грамотности, расширении кругозора, нравственного воспитания провинциального населения губернии.

Ключевые слова: просвещение, культура, интеллигенция, народные библиотеки, комитеты народных чтений, грамотность, досуг.

ностью местных помещиков в насаждении культурных достижений.

Проявление частной и общественной инициативы в области народного просвещения не ограничивались только организацией в городах и селах губернии народных библиотек, продажей книг в самых глухих местах уездов. Особенный интерес приобрела деятельность разного рода обществ и кружков, созданных в Орле и уездах в целях народного просвещения - явление также частной инициативы, объединенное усилиями отдельных лиц и имеющее более крупное значение в культурной жизни орловского края. К таким просветительским обществам относится орловский комитет народных чтений, организованный в 1886 г. по инициативе попечительства о народной трезвости в Орле. Но требования жизни заставили его, во-первых, распространить свою работу за пределы города, во-вторых, ввести в программу своей деятельности и другие задачи, имеющие отношение к делу народного просвещения: организация и открытие бесплатных библиотек-читален, книжных складов, доставки книг населению, устройство по воскресным дням публичных лекций, спектаклей, концертов с благотворительными и просветительскими целями. [1]

В Орле комитет имел две аудитории, из которых одна помещалась в зале городской думы, а вторая являлась с конца 1893 г. мастерскими станции Орел-Елец. Зал городской думы, в котором происходили народные чтения, был настолько тесен, что комитету приходилось отказывать многим желающим. Средства комитета были 
скудны, что не давало возможности нанять другое, более обширное помещение. Вход на чтения был бесплатный. Расходы комитета были особенно значительны в первый год своего существования, т.к. на первых порах приходилось приобретать все необходимые приборы и приспособления для чтений самим. Не имея средств на покупку картин, комитет брал их напрокат из московской художественной мастерской, оплачивая за это каждый раз около трех рублей. За 5 лет (с 1887 г. по 1892 г.) комитетом было устроено 235 чтений, из числа которых 111 духовно-нравственного содержания. [2]

Публичные чтения, устраиваемые для народа, имели две цели: сообщение элементарных сведений по главнейшим отраслям знаний и доставление посетителям эстетического наслаждения, предоставление народу возможности с пользой и удовольствием провести досуг в праздничные и воскресные дни.

Польза, приносимая народными чтениями, была огромна, но они посещались преимущественно рабочими, живущими в городе, а все крестьянское население лишалось возможности пользоваться чтениями. Хотя для крестьян народные чтения были более необходимы, чем для рабочего, который располагал достаточными средствами получения нужных знаний. К его услугам предоставлялись воскресные и вечерние школы, общедоступные лекции, библиотеки, читальни, театры. Всего этого деревня была лишена.

Орловский комитет народных чтений организовал проведение публичных лекций, посвященных юбилейным датам русских писателей. В 1898 г. к 20-летию со дня смерти Н.А. Некрасова комитет устроил литературный вечер в память писателя для учащихся Орла, где были прочитаны произведения писателя: поэма «Рыцарь на час», отрывки из поэмы «Кому на Руси жить хорошо». В составе лекторов приняли участие артисты театра, помощники присяжных поверенных, дворяне, учителя, губернский предводитель дворянства М.А. Стахович. Темы публичных лекций носили и научный характер, предназначенный для более образованного числа слушателей. Так в течение 1900 г. в Орле было прочитано несколько платных публичных лекций по древней истории, по биологии. [3]

Орловским комитетом народных чтений и его отделениями в уездах приглашались лекторы из Москвы, Петербурга и других городов России. Среди них были: в марте 1897 г. приват-доцент Санкт-Петербургского университета Вейберг прочитал в Орле публичную лекцию «Жорж Занд» в зале дворянского собрания; профессор Московского университета И.Х. Озеров с лекцией на тему: «Экономическая Россия в конце X1X-начале XX в.» в Ельце в пользу библиотеки для служащих земства; в период 1904-1905 гг. в Орле член орловского лекционного кружка, окончивший естественный факультет Женевского университета, М.Д. Вульфсон прочитал лекции по химии; присяжный поверенный округа Санкт-Петербургской судебной палаты Н.М. ВиленкинМинский выступил с лекцией «Нравственная проблема наших дней» и т.д. [4]

С целью облегчения распространения полезных книг в народе орловский комитет выступил в 1895 г. инициатором открытия книжного склада при комитете. Склад производил покомиссионную продажу книг в различных уездах губернии: Мценском, Орловском, Болховском. Проданные книги предназначались для крестьян этих уездов в целях организации и проведения народных чтений.

Орловский комитет помог земским школам в организации чтений, отпуская им бесплатно свои картины, иллюстрирующие эти чтения. В 1897-1898 гг. картинами комитета пользовались 7 земских школ (Орловского, Кромского, Трубчевского уездов). Всех чтений было устроено 18. [5]

Председатель правление комитета А.Н. Рейнгардт на очередном собрании в октябре 1901 г. сделал обзор деятельности комитета народных чтений. Из этого обзора можно узнать, что комитетом была ликвидирована входная плата на чтения, открыты две новых аудитории и назначена плата лекторам в размере от 1 до 1,5 руб., открыт склад для сбора и сбыта пожертвований попорченными вещами. Чистый доход с этой операции предназначался на пополнение книжного фонда Тургеневской библиотеки-читальни. Деятельность правления комитета была направлена на развитие и увеличение интереса к чтениям, а также на увеличение средств комитета, которые пополнялись от средств литературных вечеров и спектаклей - 193 руб. 83 коп., членскими взносами - 206 руб., пособием от земства - 300 руб., от думы - 250 руб., пожертвований - свыше 100 руб. Наиболее крупной статьей расходов комитета являлось содержание Тургеневской библиотеки-читальни, для которой было приобретено 117 томов книг.[6]

Для расширения своей просветительской деятельности орловским комитетом были открыты отделения народных чтений в уездах: Севском (1895 г.), Елецком (1896 г.), Карачевском (1897 г.), Кромском (1896 г.), Брянском (1895 г.). Чтения в этих уездах проводились в течение года бесплатно, дополнялись необходимыми пособиями: «волшебным фонарем», экраном, картинами и книгами. Посещались охотно, слушатели относились к ним с особенным интересом. Желающих было такое количество, что аудитории не могли вместить всех желающих, и приходилось иногда им отказывать или назначать по два чтения в день.[7] 
Чтения проводились религиозно-нравственного и церковно-исторического содержания по географии, по русской гражданской истории, по беллетристике, по естествознанию. В качестве лекторов выступали лица городского духовенства и учебно-педагогического персонала. Проводились народные чтения утром и вечером в праздничные и воскресные дни. Утром их посещали учащиеся местных учебных заведений, а вечером - взрослая публика, преимущественно мещанство и купечество. В некоторых уездах, например Севском, в антрактах ученики духовного и городского училищ пели религиознопатриотические песни под игру граммофона.

С конца 90-х годов XIX века в Орловской губернии активизировалась просветительская работа духовенства и начала проявляться инициатива частных лиц.

Инициатором публичных богословских чтений выступил орловский епископ преосвященный Никанор, который сам в 1899 г. прочитал во время великого поста в зале дворянского собрания при большом стечении интеллигентного общества богословское чтение «О бессмертии души». [7] Организацией и распределением чтений заведовал ректор орловской семинарии. Чтецами выступили ректор и преподаватели семинарии. Чтения сопровождались пением церковных песнопений, которые исполняли поочередно хоры архиерейский, семинарский и хор учениц епархиального женского училища. Чтения с пением продолжались полтора и два часа. Вход на чтения был платный. Вот некоторые темы богословских чтений: «Православие и народность, как основы истинного образования и воспитания», «Значение Пушкина в истории духовного развития русского народа», «Культурно-исторические условия в русской общественной жизни XVI-XVII в.в., вызвавшие появление раскола старообрядчества».[8]

Организаторы богословских чтений в Орле так определяли значение и цель чтений: «дать народной массе возможное расширение кругозора мысли и идти навстречу желаниям того же народа разумно, с пользой и назначением провести свободное время в праздник. Народные чтения являются одним из средств для просвещения народа и в то же время воспитания, отвлекая народ от праздности, разгула, от пустых разговоров и вообще всего, что, не давая развития душевного, дурно отражается на нравственной стороне жизни».[9] Чтения охотно посещались мастеровыми и рабочими семьями Орла.

В том же 1899 г. религиозно-нравственные чтения были открыты в зале карачевской городской думы местным городским духовенством. Всех чтений проведено 32, количество посетителей - около 200 человек. [10]

Лекторы выбирали из всех отраслей церковно-бо- гословской литературы статьи, отличающиеся живым и общедоступным изложением, назидательным и интересным содержанием. Во всех чтениях преобладал элемент церковно-исторический: читались жития святых, истории духовных праздников, статьи из священной истории.

В первой пол. 1890-х годов грамотные люди губернии начинали сообщать народу посредством чтения вслух, те знания, какие можно было встретить в изданных и одобренных для прочтения изданиях. Чтения велись домашним образом, в своем доме или в избе знакомого крестьянина, куда сходились односельчане. В роли лектора и организатора чтений выступал новый тип просветителя - грамотный крестьянин. В орловском комитете народных чтений в ноябре 1894 г. был получено письмо из Трубчевского уезда от учителя местной школы грамотности А.А. Ватковского с просьбой добиться для него разрешения читать народу: «Прошлой зимой я сделал 25 чтений, бывало по 50 человек стариков - это были чтения религиозного содержания и под наблюдением священника. Теперь же священник устраивать чтения не желает. Сделанные мною чтения оказали очевидную пользу: основалось общество, увеличилось число учащихся в школе и число молящихся в храме, явилась жажда знаний у многих малограмотных: они доучиваются и читают школьные книги. Школа моя - школа грамоты, ей 5 лет от основания, основана она на пожертвования частных лиц. Нет книг и разрешения читать». [11]

Прошения о разрешении народных чтений духовнонравственного и исторического содержания в селах подавались священником к местному архиерею, который разрешал вести чтения. Наиболее удобным временем для устройства чтений была зима, когда крестьяне не заняты полевыми работами, когда в городах происходил большой наплыв рабочих из деревень и когда лекторы, в основном учителя, могли проводить чтения. Одним из основных источников материального содержания городских аудиторий, где проводились чтения - плата за вход. Но она в свою очередь влияла на состав слушателей, который должен был состоять из бедных людей, для массы которой недоступны дорогие развлечения: концерты, публичные лекции. Пользуясь субсидией местного земства, орловский комитет народных чтений для самых бедных слоев населения вводил бесплатный вход.

На Бежицком заводе Брянского уезда народным чтениям для рабочих и мастеровых завода придавалось важное значение. В январе 1895 г. директором завода было получено разрешение орловского губернатора о проведении народных чтений. Чтения открылись в бесплатно предоставленной народной столовой княгини М.К. Тенишевой. Каждое чтение сопровождалось «туманными картинами» и пением хора певчих. Плата за вход на чтения составляла 2 коп. Всех чтений в народной сто- 
ловой с января 1895 г. до весны 1896 г. было 26, которые посетило 60255 рабочих. Картины для чтения выписывались на прокат за плату из московской художественной мастерской. 200 картин было приобретено в собственность, большая часть из них, вместе с волшебным фонарем, пожертвованы попечительницей школы княгиней М.К. Тенишевой, а остальные приобретены на средства завода. [12]

В самом Брянске отделением комитета народных чтений проводились чтения в здании городского училища и в зале городской думы.

Неблагополучно обстояла организация народных чтений в селах Брянского уезда. Об этом жаловались корреспонденты «Орловского вестника»: «Среди населения царит пьянство, безобразие. Как устранить коснеющий мрак и невежество, как приучить народ к мышлению? С этой целью устраиваются зимою чтения с туманными картинами. Но чтения не достигают никакого результата. Чтениями руководит «интеллигенция», и мастеровые, хотя и охотно посещают аудиторию, но смотрят на чтения, как на средство позабавиться. Такое ненормальное отношение объясняется, во-первых, отсутствием хороших лекторов, обладающих живым словом, которые могли бы повлиять на слушателей; во-вторых, плохим подбором книг для чтения». [12]

Хотя публичные чтения не всегда находили должного отношения в крестьянском населении, все же они в какой-то мере способствовали просвещению народа Орловской губернии.

Расширение просветительской деятельности комитета и частных лиц активизировало церковь с конца 1890x г., которая стала организовывать публичные чтения, концерты церковных песнопений. Тематика публичных чтений носила не только богословский и религиозный характер, но и отчасти литературный и исторический.

Таким образом, организации народного просвещения объединяли орловскую интеллигенцию, искавшую выход своей творческой энергии, желавшей реализовать накопленный интеллектуальный и художественный потенциал. Естественная тяга людей к духовному общению, а также небогатая развлечениями жизнь горожан и сельчан способствовали росту численности просветительско-культурных объединений.

Еще одним плодотворным направлением деятельности организаций народного просвещения губернии явилось нравственное воспитание населения.

\section{ЛИТЕРАТУРА}

1. ГАОО.Ф.580.0.1.Д.5916. 0 существующих обществах распространения образования и грамотности в народе.1893.Л.5.

2. Пругавин А.С. Запросы народа и обязанности интеллигенции в области просвещения и воспитания. - СПБ.-1895.- С.138.

3. ГАОО.Ф.580.0.1.Д.3979.Программы лекций.1900.Л.1.

4. Орловский вестник.1897.№47.18февраля.

5. ГАОО.Ф.580.0.1.Д.2745. Рапорт о проведении лекций, чтений.1897.Л.2.

6. Орловский вестник. 1901. № 283.26 октября.

7. Орловские епархиальные ведомости.1900.№ 16.С.648.

8. Орловские епархиальные ведомости. 1900.№19.7 мая. С.734.

9. Орловские епархиальные ведомости. 1900.№ 25.17 июня. С.986.

10. Вахтеров В. народные чтения.// Русская школа. СПб.-1896.- Кн.7.- С. 245.

11. Орловский вестник.1897.№ 4.5 января.

12. Орловский вестник.1905.№ 45.15 февраля. 